\title{
Invaluable narratives on long life: A multiple case study
}

\author{
Gloria P. Gempes* \\ University of Mindanao, Davao City, Philippines
}

\author{
Keywords \\ Long life \\ Octogenarians \\ Narratives \\ Multiple case study \\ Philippines
}

Received: 13 February 2018

Accepted: 20 March 2018

Published: 18 April 2018

\begin{abstract}
The purpose of this qualitative multiple case study was to find out the longevity practices of healthy and happy octogenarians who have long retired from their full employment in the academe. This study contains the longevity practices of three cases gathered through in-depth interviews involving two women and one man with ages 82, 85, and 88, coded as Grandma Bag, Papa Harry, and Fertile Granny. For triangulation, three persons who personally knew the subjects were also interviewed for each case. What enabled these animated octogenarians to live so long is an invaluable life lesson to be profoundly considered. Seven themes common to the three cases and three case-distinct themes were generated from the study through content analysis and cross-case analysis. The themes were the practices for the long life of the three octogenarians. The longevity practices common to all three cases are as follows: being happy, church involvement, regular check-ups, work engagement, healthy diet, exercise, and socialization. For the unique practices in each case, they are as follows: observance of 10-minute reaction time before any activity for Case A, helping the needy for Case B, and no to bottled water and drinks for Case C. The result of the study is beneficial to the succeeding generations, especially the retiring sexagenarians (aged 60-69) in the academe, who are beset with stressful pedagogical activities.
\end{abstract}

(C) 2018 The Author(s). Published by TAF Publishing.

\section{INTRODUCTION}

The desire to live a healthful and longer life has been an aspiration of the human race in all parts of the world. But is it worth living a longer life when you are no longer functionally healthy? Dependence on somebody to do one's personal basic physical activities is undesirable (Moore \& Durstine, 2016). But are there measures to manage age-related health problems? Because as we age, pain does become a more prevalent problem (Beshai, 2014). As one famous adage goes, "Aging is not without pain". This does not mean, however, we must live with the pain. In fact, the photos of happy octogenarians can be seen on the social media. They could provide a model, one can inquire into their lives, particularly on the measures in managing age-related issues on longevity.

One octogenarian who was featured in the Daily Mail Reporter (2014) along with her statement: "At 82, I am far happier than I was in my 60s", caught my attention. She is an award-winning playwright and author Fay Weldon, who is 82 . The article triggered my interest. It leaves me wondering if healthy octogenarians are by and large extant, particularly in the local setting. It seems unbelievable because looking around, we can see sexagenarian retirees, aged 60-69 suddenly succumb to death or lying on their sick bed after a couple of years or so, an obvious failure in life adjustment from active working status to a sedentary one. This phenomenon is observable in the academe where I am associated with. Weldon is a writer and perhaps leading a stress-free life compared to teachers who are beset with taxing pedagogical activities.

The researcher in me keeps pounding my inner consciousness for a concrete answer whether there are healthy octogenarians among retired educators. This question, along with the desire to provide a tangible record of healthy practices if ever they exist, pushed me to do this research. The record could be an inspirational guide for retiring teachers wanting blissful and healthier lives despite of advanced age which is normally associated with various agerelated changes (El-Magd \& Zaki, 2015) that may affect their lifestyle. Common age-related physical changes in-

\footnotetext{
*corresponding author: Gloria P. Gempes

†email: gpgempes@gmail.com
} 
clude hearing impairment, weakening vision, and the increasing probability of arthritis, hypertension, heart disease, diabetes, and osteoporosis.

An inquiry on the longevity practices of healthy octogenarians from the academe is expected to make a worthwhile contribution to the existing database on long life of retired teaching force. This may serve as a prototype for this cohort of professionals to spend their later lives in an atmosphere of delightful existence regardless of advanced age. This will be a tool in understanding the mechanisms needed in the improvement of one's health in later life. The results of this study may inspire concerned policy-makers to craft interventions for working older adults and prospective retiring teachers, like mapping effective health promotion strategies to achieve healthy aging for older teachers. After all, the teachers are our moulders of the future generation.

\section{Purpose of the Study}

The purpose of my qualitative multiple case study is to look into the practices of healthy octogenarian (aged 80-89) educators with the aim of crafting a tangible list of health practices on longevity direct from the horse's mouth and not from secondary sources. Their testimonies will serve as a blueprint, a tangible guide for retiring educators who desire to lead blissful, healthy, and longer lives. Research questions are designed as follows: What are the common health practices of healthy octogenarian educators? What is the distinct health practice of each participant which he/she considers valuable for longevity? Being healthy means independent of disease prevalence and poor functional status (Kelley-Moore, Schumacher, Kahana, \& Kahana, 2006).

\section{REVIEW OF RELATED LITERATURE}

Studies on longevity of oldest olds complemented with good health are scarce (Beard et al., 2016; Chatterji, Byles, Cutler, Seeman, \& Verdes, 2015), thus the need for response to this kind of undertaking. This makes my study a fitting document to this pronouncement by this group of authors. Healthy and happy at age 80 seems rare in the contemporary milieu. Several longevity studies underscored the factors of long life (Edelman, Mandle, \& Kudzma, 2017; Fischer \& Noland, 2014; Greenstein \& Holland, 2015) distinctively, whereas my study covers the entirety of the individuals involved, narrating what makes them live longer and still healthy at age 80 . The distinctive coverage of factors of aging can be seen in the literature that follows.

In the study of Mineo (2017) on socialization as a factor of longevity, he conveyed that those who had happy relationships at age 50 turned to be the healthiest at age 80 . There- fore, it can be argued that involvement in social groups is a predictor for healthy well-being in later life which started at earlier age. This is an articulation of the theoretical lens of Continuity Theory (Atchley, 1989) which states that individuals who age successfully continue habits, preferences, lifestyle, and relationships through midlife and later. Other factors, like church involvement and work engagement even at later life, could find parallelism with socialization. Because these two factors of longevity involve interpersonal relationships with other people. As advanced by a number of authors (Chen \& Feeley, 2014; Jetten, Haslam, Haslam, Dingle, \& Jones, 2014), there are notable evidences existing that individuals can draw on social groups for support as mechanism in maintaining health and well-being leading to increase in life span.

Regular exercise is another important element of longevity. In a study of 1,635 sedentary adults in their 70 s and 80 s, a conclusion was drawn that 20 minutes of brisk walking a day can help elders sustain mobility (Shah, 2014). This is an affirmation of activity theory as one of the lenses of this study. Activity Theory (Knapp, 1977) takes place when individuals engage in a full day of activities and maintain a level of productivity to age successfully. People who remain active and engaged tend to be happier, healthier, and more in touch with what is going on around them. According to some authors (Corbin, 2002; Lyubomirsky, 2008), being active is one of the best life choices to maintain or improve one's health. Activity enables a person to stay strong physically and maintain independence, in the case of older adults, for as long as possible. Moderate amounts of aerobic physical activity can reduce approaching functional decline among the oldies allowing them to continue with their basic activities independently. On the other hand, physical inactivity (Sharkey \& Gaskill, 2013; Wei, Gibbons, Kampert, Nichaman, \& Blair, 2000) can lead to unnecessary illness and loss of ability to handle daily tasks as well as independence. Physical inactivity is also associated with higher mortality rates. Moderate exercise along with healthy diet provide important impetus towards successful aging. According to Willcox, Scapagnini, and Willcox (2014), one important factor of longevity is a healthy diet. Dietary patterns are associated with reduced risk for cardiovascular disease, among other age-associated diseases and promote healthy aging and longevity.

\section{METHODOLOGY}

\section{Research Design}

Having no idea how many healthy octogenarian educators might be existing, I decided to embark on a qualitative mul- 
tiple case study. According to Creswell and David (2017), a sample of 2-5 for a multiple case study will be sufficient. This design will be advantageous when what, how, who, and why questions are being asked, or when the focus is on a contemporary phenomenon within a real-life context (Wheeler \& Holloway, 2004). Yin (1994), on the other hand, confirmed that case study is a rigorous method of research. Yin (1994) stressed that the need for case studies is based on the desire to understand complex social phenomenon. It permits the researcher to maintain real-life events.

My attachment to the world of the academe is my motivation for pursuing this study on finding out what are the health practices of healthy octogenarian educators. The findings may inspire and motivate the prospective retiring teachers in adapting the practices for longevity obtained directly from the horse's mouth. Purposeful sampling was used to select the participants of this study. According to Patton (2002), the logic and power of purposeful sampling lie in selecting information-rich cases for in-depth study. I used intensity sampling which allows me to choose information-rich cases that present the phenomenon of interest who were the octogenarian educators. Homogeneous sampling was also used to narrow the focus of the study to all educators. Patton said that homogeneous sampling allows the researcher to describe a particular subgroup in greater depth.

\section{Participants}

It took me two years to come up with my three samples. My friends and colleagues referred me to some octogenarians but they did not satisfy my inclusion criteria of a healthy octogenarian educator. All those referred to me were already sick and had cognitive problems. There was an 81-year old I happened to meet but she was not an educator, a retired supervisor in an apparel company. Fortunately, I met an 88-year old retired educator, through referrals from influential persons, still functionally healthy being a part time curriculum consultant in one of the private schools in Davao City. I found her very amiable and accommodating. The guard of that school even helped me to locate another healthy octogenarian educator, aged 82. I happened to converse with the guard on one occasion while waiting for my subject, since he asked me what was my purpose in regularly seeing the old lady. My third participant was a male octogenarian educator from Northern Luzon who happened to take his vacation here in Davao City with one purpose of viewing the residence of the newly elected President, then, Rodrigo Duterte. My male participant's daughter was my sister's classmate way back in their college days. My sister was instrumental in finding my male participant.

My participants' names were coded in accordance with their dominant characteristics. Case A, aged 82, was named Grandma Bag, for her exceptional hobby of collecting ukayukay (second hand) signature bags. Case B, aged 85, was named Papa Harry for his striking resemblance with Clint Eastwood's character in Dirty Harry, tall, lanky, and rugged. Case $\mathrm{C}$ was named Fertile Granny having twelve children and countless grandchildren.

\section{Data Collection}

It is important that I gain the confidence, trust, and support of each participant. Firstly, permission to conduct the study was obtained from each participant emphasizing that their involvement is voluntary, that they may not answer any of the questions, and that they can withdraw anytime from the interview. Complete anonymity was discussed with each participant and they were assured that all responses, including identity and personal information, would be treated with utmost confidentiality. They were made to sign the needed informed consent which is part and parcel of research ethics in qualitative research.

I personally conducted the interview in multiple phases with each participant. I did the translation of the transcript as well as the encoding of both transcripts and translations. I have also personally analyzed the data of this study through content analysis. Patton (2002) described it as "any qualitative data reduction and sense-making effort that takes a volume of qualitative material and attempts to identify core consistencies and meanings". A separate within-case analysis was made for each case followed by cross-case analysis. Each of the with-in case analysis gave detailed and rich descriptions of the case. In the cross-case analysis, my research questions were addressed by using all the data gathered from the three cases and summarized into major themes and core ideas.

\section{Data Analysis}

In this aspect, analytic process was done starting from the encoding to the organization of data and, importantly, in the crafting of core ideas and emerging themes. The raw data and encoded transcripts had to be read several times for thorough understanding and interpretation. Gay, Mills, and Airasian (2009) stated that researchers can establish the trustworthiness of their qualitative research studies and findings by addressing all Lincoln and Guba (1985) criteria for validity namely credibility, transferability, dependability, and confirmability. I had met and achieved the criteria by doing the following activities: For triangulation, I man- 
aged to interview three informants for each case who knew the case participant. This was done to measure the authenticity of the information gathered from the main interviewees. I had requested my co-researchers and friends to do peer debriefing by listening, prompting, and recording my insights through the entire conduct of the research; I had done persistent observation in the conduct of face-to-face interview with each participant; I had checked my analyses and interpretation that all accurately reflect the documents and recordings; I had collected audio recordings and interview notes; I had provided each participant with the copies of the transcripts and translations for checking and feedbacking, so as to avoid conflicts and contradictions as a process of member check.

\section{RESULTS}

The personal account of the three participants of my study are presented in this section. Their important utterances are illustrated in italics to provide the readers the sense that they are talking directly to my three cases. Though the research question is mainly on the health practices of healthy octogenarians, two of my participants offered some information beyond the data needed.

\section{Case 1 (Grandma Bag)}

I assigned a code name of Grandma Bag for Case 1 since she has a vast collection of signature bags (not the brand new ones, but from ukay-ukay). She is 82 years old. Her husband is still alive who is three years younger than her and also a retiree from a manufacturing company in Cebu. Grandma Bag is a retired secondary school teacher. She has worked in a private school in her earlier years of teaching but later transferred to a public school long before her retirement. Compared to her husband, she is relatively healthier. She finds happiness in her collection of signature bags much more if there is an additional item in her collection. She claims that her bags are among the things that make her healthy. She is busy with her bags every day for wiping, rearranging, inspecting the inside sections, and putting some solutions on the leather to make them shiny. She is spending two to three hours every day that make her perspire which is healthy I suppose. She makes it a point that she is finished with her activity few minutes before lunch. She brags that a number of interested ladies have already offered her a sizable amount of money for her collections but she graciously negated them.

The couple is living with their modest pensions and regular support from their four children, all married. Their children have their own homes within the city and who visit them every weekend, except their youngest who married a foreigner and is living abroad. She finds full support from her children as regards her hobby, though her husband finds her weird. If there are special occasions, her children will not bother anymore scouting for a gift for their mother. They know what keeps her happy. Her husband has his reason of finding his wife a weird one because when one of their children gave her a brand new signature bag on her birthday, she was so worried and forlorn knowing how expensive the signature bag is that it must have sliced a substantial amount from the family budget of her daughter. That incident was a big lesson to her children. She divulged to them that having a signature bag at a very low price is what makes her happy. Looking at her collections, though, will give anybody an impression that the bags are all brand new maybe because of the care she showered to her collection regularly. When she professed her happiness about her bags, I asked her if there are other things that make her happy. I could sense a sparkle in her eyes when she answered me:

"Yes, when my husband stopped smoking for a decade now. I know very well that it will not only shorten his life but mine too as a secondary recipient of the smoke coming from his cigarette. At the time he stopped smoking, my regular bout of colds has also stopped. He realized the negative effect of smoking on his health after experiencing a number of illnesses coming usually in pairs. After a year, he may become an octogenarian but he is suffering from sore throat and canker sores every now and then, even if he has already stopped smoking." Our first meeting was more of an acquaintance, knowing her life story and highlights of being a teacher, which according to her is another source of her happiness during her work life. She loves her past job as a teacher, and she has loved her students, treating them as her own children. She narrated that some of her students were problem fellows in other subjects but inside her classroom her students were very participative, animated, and very punctual. She believes that she was able to inculcate to them the value of punctuality, much more to her own children. She makes it a point that she is in the venue at least 10 minutes before the scheduled time, may it be in the classroom or in a seminar or any activity for that matter. This practice according to her will put stress at bay.

In our second meeting, I probed further on the things that contributed to her longevity as an octogenarian, though I had already the idea that her being a happy person is very elemental to her well-being. She keeps on smiling. Below is her reply, among other things:

"Problems are a part of the lives of a person. If you don't have problems means you are dead. I approach problems with a 
positive thought that by tomorrow, it is no longer there. I don't care how many tomorrows I will be counting but I am very positive that it will pass and it really happens. Be happy and it attracts happiness; be sad and you will experience sadness more than double."

Grandma Bag also boasts of her achievement as a mother, another source of happiness, because with the support of her husband, all her four children were able to finish school and have successful family life with healthy normal kids. She loves her grandkids as much as she loves her children but she makes it a point that she does not spoil them. She believes that her children regarded her and her husband as their role models for a successful marriage. She confessed though that during their early marriage, it was not as smooth as in the later years, but they were able to conceal from their children whatever differences they had in the beginning.

She added that after the marriage of their youngest daughter, they made it a point to travel outside the country once a year and see the world through promo fare, sometimes with the company of one of their children including the family, and sometimes with the company of a relative. She does not forget to thank God every minute of her daily undertaking, practically for all the things she has in her present life. She and her husband have their annual check-up before taking any vacation. The vacation serves as the goal the couple desires to achieve on an annual basis. She and her husband are not attending Sunday mass since her husband could not endure standing for longer periods, which usually happens during Sundays with so many people attending the mass. However, they regularly attend mass on weekdays, usually on a Monday where many seats are available.

Grandma Bag still accepts English tutorial of foreign students whom they have met abroad and decided to have their schooling in Davao City. Her limit is two students only in the afternoon from 4:00 to 6:00 pm., scheduled three times a week. This is just to keep her mind on the go, according to her. During Sundays, she and her husband usually stay at home, waiting for their children's visit after their Sunday masses. With the help of a distant relative who is living with them, the food of the couple is made distinct from the general food preparation. Theirs are plainly fish, vegetables, and fruits. On some occasions, some neighbours join them in their Sunday get-together, where they do Zumba with her daughter as the lead dancer. Their lawn is big enough for the activity with lots of trees around the place.

My succeeding encounter with her is sort of member check which is part and parcel of a qualitative research. I showed her my transcripts and discussion with the promise that her identity will be made confidential. There were some transcripts that she requested not to be included and I obediently complied.

\section{Case 2 (Papa Harry)}

I named my second case as Papa Harry because he looks like the famous Dirty Harry (Clint Eastwood), lanky and tall. He is 85 years old. His wife died 14 years ago. He did not remarry because he loves his wife so much. I could sense it in my conversation with him. And one thing more, his daughter is quite stern. He has a 19-year old grandson who lives with him and is still pursuing a college degree. Papa Harry was the former principal in one of the elementary public schools in Northern Luzon. After retiring at age 65, he developed his farm in Quezon province. Most of his relatives, mother side, are living in Davao City. He is on a one-month vacation in Davao City with his daughter who happened to be the classmate of my sister who informed me about him coming to Davao City. My sister knew that I was searching for a healthy octogenarian educator. Papa Harry's visit to Davao is his desire to see the residence of our President Rodrigo Duterte.

My first meeting with him was marked by some reservations. Through the prodding of his daughter who was already oriented by my sister, eventually he welcomed my intention and he signed the informed consent. I promised him not to take much of his time and that we will stop our conversation within an hour. I met him two times. I discovered during the succeeding meeting that he is a jolly person, though he is not as open as Grandma Bag with some of my questions. He told me that aside from seeing the house of the President, he is interested in herbal plants here in the City so he could propagate them in his farm. He still works in his farm early in the morning catching the early sunlight, in spite of his age. He allocates at least an hour every morning to his farm, except on rainy days. Looking at him, one could still mistakenly adjudge him as a 60-year old. He has his hair dyed regularly done by his daughter. When I probed into his longevity practices as an octogenarian, he willingly shared them with me: "My diet is basically that of a farmer; vegetables and fruits, all fresh. For my meat, I have my native chicken in the farm. I seldom eat eggs. I eat pork or beef in moderation but only on rare occasions, when there is a celebration. I do not sell the eggs which abound in the place laid by my native hen. I gave them to some poor families who live in the vicinity of the farm. I found happiness in giving, knowing that at least in a day, they have one meal complete with a nutritious viand. At first, my daughter was adamant about it but ultimately, she supported my pursuit." 
Her daughter, who was listening nearby, added that aside from the eggs, his father is giving vegetables as well. But the beneficiaries of his father's generosity are good people because they offer their free services to the farm once they know that a worker is having his vacation or is unable to tend the farm for personal reasons. And they guard the farm voluntarily from crooks without the instruction from his father.

During the second meeting, Papa Harry, had a good laugh when I told him that I coded him as such because of his resemblance to Clint Eastwood. It is also on this occasion that I did my member checking, particularly the result of the transcripts in the first meeting. I read to him also the transcripts of the day's meeting and the possible discussion I would make to call off the third meeting. Our meeting for that day lasted for two and a half hours. He made some revisions and improvements of the items to be considered. He revealed more longevity practices during the second meeting:

"I am a non-Catholic but most of my buddies are Catholics and very much younger than me. The majority of them have already hypertension, diabetes, arthritis, and a host of other diseases. I advised them of my lifestyle because they kept on asking how I sustained my health. But they dismissed it by saying that it is very hard and that fresh fruits and vegetables are very expensive in the poblacion."

"Though the poblacion is quite far, I see to it that I am never absent in my weekly church obligations, thanking the Lord for his gift of long life. And this is one occasion where I can use my best clothes unlike when I was still in school. However, my daughter won't allow me to go without somebody to go with me. My daughter and I have different religions. Though I am still functionally healthy, movement is no longer as fast compared to my younger days. There is a barangay health center in our place. This is another occasion where I can wear my non-farming clothes since I go to the center monthly for check-up."

"I try my best to be active as possible, mentally and physically. I have a daily subscription of a newspaper and the crossword puzzle is one of my favourite sections. But by being physically active, I take precautions and wise choice of the activity I engage with. Like I refrain myself from cycling, though at times, I find it very tempting. Falling and having fracture is a no-no for seniors. Healing is quite impossible. I sleep early, I wake up early for the sunlight. I think this is one important practice for my longevity."

I thanked Papa Harry and her daughter for the sharing but he had one obligatory request that he be given a copy of the final paper, which I did right after the completion of my study.

\section{Case 3 (Fertile Granny)}

My third case is an 88-year old lady, a widow, who is still working as a part-time curriculum consultant of a private school in Davao City. I coded her as Fertile Granny and she loves it. She has 12 children and a host of grandchildren, which she refused to divulge the number. She has her personal reasons. I made four meetings with her. First meeting was an overture and initial inquiry on her family background and some preliminaries of the core of the study, 2nd was on the main intention of the study, 3rd was on the confirmatory aspects of the results of the previous inquiries, and 4th was the member check. She was also a researcher during her prime years as a teacher. She has teaching experiences in the elementary, secondary, college, and graduate education, both in public and private schools.

As a researcher, she suggested that in presenting the results of my interview with her, I go direct to the research question and reserve the other data for other researches. I submitted to her proposition. But I asked her permission to describe her health condition. Just like Papa Harry, Fertile Granny has functional health. In terms of physical health, she is no longer as fast-moving as she was in her 60 s and 70 s, but she can still manage to do the basic function of a person without an illness. The fact that in her agreed schedule with the school, she can still do the cognitive tasks assigned to her, which indicates that she is able to sustain her health in spite of the advanced age. Obviously, the school still needs her expertise. When asked what her health practices for longevity are, she has this to say:

"I believe it is in my genes, but of course, genes will be useless without complementing it with well-researched health practices. I have never tasted bottled drinks since birth. I was raised in a paradise-like farm with all the greeneries and domesticated animals. We did not have any problem with food. Everything was at hand. Even during the time that bottled water was introduced to the market, I did not attempt to taste it. And I did not expose my growing children, then, to bottled water. Although in their adulthood, they became regular user. I made some extensive research on bottled water. As a result, I decided not to use it and so with my husband when he was still alive."

When I asked her about her personal research on bottled water, she told me to do my own so that I will get the firsthand information. Talking to a researcher is really distinctive. You can obtain answers that are atypical. After the topic on bottled water, she gave me a long list of her practices which she believes are contributory elements to being 
a healthy octogenarian. By healthy, she means free of degenerative diseases, although she admitted that she had one operation for cataract in her 70s. The list is as follows:

"I go to church regularly not only on Sundays, to thank the Lord for the gift of life. I am happy and satisfied with all the things I have right now. I have my family doctor to visit me at home every now and then to check my health status. His retainer fee is shouldered by my daughter in Italy. He has no objection with my consultancy work. He finds it beneficial for my mental acuity. I am an organic practitioner. I go for healthy foods. I hate junk foods, especially when I see my grandchildren consuming them pouch after pouch. I do walking around the house starting at 5:00 pm for 20 minutes. This enables me to sleep soundly when I retire in the evening. I go for herbal remedies rather than the conventional pills. I always do research when I need to address an issue. Our monthly family gathering involving my children and my grandkids gives me the feeling that I am still young and able, especially hearing the joyful laughter of the kids running to me for assistance." The information I obtained from my three cases is worth a fortune so to speak. What they have mentioned are valuable things that I have no concern of in my younger days. However, as of date, the knowledge I gained from them is very useful as a working sexagenarian.

\section{DISCUSSION}

The three cases are all free from chronic diseases of aging despite of their advanced age. They mentioned, though, that at times they could feel occasional minor pains in some body parts. However, they could easily manage them with gentle massage. Case A, however, declared of being pain-free, and she attributes it to Zumba and her strict diet of sugar-free and oil-free foods having a special utensil for the purpose, a gift from her daughter abroad. And she drinks lots and lots of water. From the results of the study, it could be gathered that there are seven dominant themes or health practices for longevity that are common to the three cases and these are: being happy, church involvement, regular checkup, work engagement, healthy diet, exercise, and socialization. The three distinct themes are reaction time of at least 10 minutes before any schedule (Case A), helping the needy (Case B), and no to bottled drinks/water (Case C). These themes are the practices of the octogenarians which may serve as lasting exemplars for academicians wanting to settle for a blissful retired life. Below is the discussion of each theme generated from the results of the study.

Being happy is one of the seven common themes generated from the study, a substantiation of the claim that people are happiest in their 80s, thankful of their being octogenarians, a confirmation of the claim of Weldon (2014) that 80s can be the happiest years of one's life. Grandma Bag finds happiness in her signature ukay-ukay bags, Papa Harry's happiness in giving his farm produce to the needy, and Fertile Granny in being happy and satisfied with what she is now. According to Diener and Chan (2011), happy people live longer: Subjective well-being contributes to health and longevity. In comparison, I happened to talk to a couple of retired sexagenarians and they declared they are not happy. The reason must be the sexagenarians are not yet well-adjusted from a busy life to a sedentary life.

Several studies have documented that an active religious life like church involvement is associated with long life. Case A has never been absent in her weekly attendance to the mass with her husband, so with Case B in spite of the distance of the church from his place, while Case $\mathrm{C}$ attends mass not only on Sundays but other days as well. Krause (2006) claimed that certain patterns of religious involvement do impact the quality of life of older adults and that religiosity does have physical- and mental-health benefits. It could be stated, then, that the religiosity of my three participants contributed to their long life.

Regular check-up is elemental in monitoring one's health condition to put off impending illnesses and this is being observed by my three participants. All the three cases are still actively working, although part-time in the cases of A and $\mathrm{C}$, while $\mathrm{B}$ is regularly tending his farm exposing himself to early sunlight or Vitamin D. They swear that when they will stop working, it will be their end. This is congruent with the declaration of Bonder and Dal Bello-Haas (2017) that engagement in work makes an elderly feel that he/she is still needed which gives a sense of happiness and enjoyment which, according to Veenhoven (2009), lengthens life. The working lives of my three participants are secured with healthy diet including vitamin supplements and regular exercise. These two practices which are vital in maintaining a healthy life for people of all ages give more impact on the general well-being of older adults (Moschis \& Mathur, 2007; Willett, 2017). Belonging to the workforce is the key to their socialization which is very important for a long life (Iwamasa \& Iwasaki, 2011).

In terms of case-distinct themes, Grandma Bag's early reaction time to any scheduled activity is her way of avoiding stress. This has bearing to the declaration of American Psychological Society (2005) which affirmed that reaction time is associated with long life. Papa Harry's act of giving some of his farm produce to his poor neighbours is in observance of his grandmother's declaration that every time a person helps somebody heartily, that person gains additional count 
to his/her life span. He has been practicing this from the time he got employed up to his present state as a farmer. His action is aligned with the pronouncement of Post and Neimark (2008) that simple act of giving results into living a longer, healthier, and happier life. Fertile Granny, on the other hand, has never tasted any bottled drink since birth, being an organic practitioner. According to her, even bottled water has potential dangers and her claim is congruent with an article (Krachler \& Shotyk, 2009) on the hazards of bottled water. She goes for tap water.

\section{IMPLICATIONS FOR PRACTICE}

Both the common themes and the case-distinct themes are important concerns for consideration by academicians, especially the retiring sexagenarians if they intend to live healthy long lives, and be happy on their 80th birthday. After retirement, this cohort of teachers may plan for a parttime work engagement as done by the three participants of this study. From the insights of the participants, it could be gathered that the practice for longevity is not a one-shot deal but a lifelong pattern which includes a combination of complementary activities. Importantly, the results of this study have implication to the teaching profession in meeting the challenges of aging not only for the sexagenarians but also for the younger cohort of teachers. Preparation for later life, as in the case of Papa Harry who invested in a farm during the earlier stage of his profession, is an intelligent undertaking which could be emulated by younger genera- tion of teachers.

\section{CONCLUSION}

Regular check-up, work engagement, healthy diet, exercise, and socialization as well as the case distinct practices like reaction time, helping the needy, and no to bottled water and drinks, as generated from the responses of the participants, are methodically underscored across the three cases. Several studies on aging point to financial inadequacies of oldest olds, but the participants of this study have not underlined this issue. Is it because the three of them are educators in their prime years and intelligent enough to plan for their retirement? Or they are just lucky to have successful children who could support them or has been able to invest in a farm in preparation for retirement. This is one limitation of this study that although the number of samples is within the standards of multiple qualitative case study, it failed to include an octogenarian with financial difficulties. There are octogenarian educators who might have fit this requirement but they are no longer functionally healthy.

\section{LIMITATIONS AND RECOMMENDATIONS}

The difficulty of looking for a healthy octogenarian contributed to the limitation of this study. This limitation, however, is a fertile ground for future research that will cover a diversified sample adopting another qualitative approach, preferably a phenomenology that may involve more number of participants compared to a case study.

\section{REFERENCES}

American Psychological Society. (2005). Think fast: Reaction time and IQ may predict long life, science daily. Retrieved from https://goo.gl/XdyZ3Q (accessed on 15 July 2017)

Atchley, R. C. (1989). A continuity theory of normal aging. The Gerontologist, 29(2), 183-190. doi:https://doi.org/10.1093/ geront/29.2.183

Beard, J. R., Officer, A., de Carvalho, I. A., Sadana, R., Pot, A. M., Michel, J.-P., ... others (2016). The world report on ageing and health: A policy framework for healthy ageing. The Lancet, 387(10033), 2145-2154. doi:https://doi.org/10.1016/ s0140-6736(15)00516-4

Beshai, A. J. (2014). Aging elderly pain. Retrieved from https://goo.gl/JA4T5 (accessed on 23 October 2015)

Bonder, B. R., \& Dal Bello-Haas, V. (2017). Functional performance in older adults. Philadelphia, PA: FA Davis.

Chatterji, S., Byles, J., Cutler, D., Seeman, T., \& Verdes, E. (2015). Health, functioning, and disability in older adults-present status and future implications. The Lancet, 385(9967), 563-575. doi:https://doi.org/10.1016/s0140-6736(14)61462 $-8$

Chen, Y., \& Feeley, T. H. (2014). Social support, social strain, loneliness, and well-being among older adults: An analysis of the health and retirement study. Journal of Social and Personal Relationships, 31(2), 141-161. doi:https://doi.org/ $10.1177 / 0265407513488728$

Corbin, C. B. (2002). Physical activity for everyone: What every physical educator should know about promoting lifelong physical activity. Journal of Teaching in Physical Education, 21(2), 128-144. doi:https://doi.org/10.1123/jtpe.21.2.128

Creswell, J. W., \& David, J. (2017). Research design: Qualitative, quantitative, and mixed methods approaches. New Yor, NY: Sage publications. 
Daily Mail Reporter. (2014). Despite the aches, we're most content in our 80s: Elderly are happier than those in their 60 s because they feel it is an achievement to reach old age. Retrieved from https://goo.gl/Wrwv2h (accessed on 1 January 2017)

Diener, E., \& Chan, M. Y. (2011). Happy people live longer: Subjective well-being contributes to health and longevity. Applied Psychology: Health and Well-Being, 3(1), 1-43. doi:https://doi.org/10.1111/j.1758-0854.2010.01045.x

Edelman, C. L., Mandle, C. L., \& Kudzma, E. C. (2017). Health promotion throughout the life span-e-book. New Jersy, NJ: Elsevier Health Sciences.

El-Magd, M. H. A., \& Zaki, S. M. (2015). Effect of structured physical exercise program on older adult's daily living activities and cognitive functions. International Journal of Advanced Nursing Studies, 4(1), 16-32. doi:https://doi.org/10.14419/ ijans.v4i1.3789

Fischer, E., \& Noland, J. T. (2014). What's so funny about getting old. New York, NY: Simon and Schuster.

Gay, L. R., Mills, G. E., \& Airasian, P. W. (2009). Educational research: Competencies for analysis and applications, student value edition. Upper Saddle River, NJ: Merrill.

Greenstein, M., \& Holland, J. (2015). Lighter as we go: Virtues, character strengths, and aging. Oxford, UK: Oxford University Press.

Iwamasa, G. Y., \& Iwasaki, M. (2011). A new multidimensional model of successful aging: Perceptions of Japanese American older adults. Journal of Cross-Cultural Gerontology, 26(3), 261-278. doi:https://doi.org/10.1007/s10823-011-9147 $-9$

Jetten, J., Haslam, C., Haslam, S. A., Dingle, G., \& Jones, J. M. (2014). How groups affect our health and well-being: The path from theory to policy. Social Issues and Policy Review, 8(1), 103-130. doi:https://doi.org/10.1111/sipr.12003

Kelley-Moore, J. A., Schumacher, J. G., Kahana, E., \& Kahana, B. (2006). When do older adults become "disabled"? social and health antecedents of perceived disability in a panel study of the oldest old. Journal of Health and Social Behavior, 47(2), 126-141. doi:https://doi.org/10.1177/002214650604700203

Knapp, M. R. (1977). The activity theory of aging an examination in the english context. The Gerontologist, 17(6), 553-559. doi:https://doi.org/10.1093/geront/17.6.553

Krachler, M., \& Shotyk, W. (2009). Trace and ultratrace metals in bottled waters: Survey of sources worldwide and comparison with refillable metal bottles. Science of the Total Environment, 407(3), 1089-1096. doi:https://doi.org/10.1016/ j.scitotenv.2008.10.014

Krause, N. (2006). Social relationships in late life: Handbook of aging and the social sciences. California, CA: Elsevier.

Lincoln, Y. S., \& Guba, E. G. (1985). Establishing trustworthiness. Naturalistic Inquiry, 289(45-67), 331.

Lyubomirsky, S. (2008). The how of happiness: A scientific approach to getting the life you want. Uppar Siddle Reiver, NJ: Penguin.

Mineo, L. (2017). Good genes are nice, but joy is better. Harvard Gazette, 3(6), 34-40.

Moore, G., \& Durstine, J. L. P. (2016). Acsm's exercise management for persons with chronic diseases and disabilities, 4E. Nwe York, NY: Human Kinetics.

Moschis, G. P., \& Mathur, A. (2007). Baby boomers and their parents: Surprising findings about their lifestyles, mindsets, and well-being. Ithaca, NY: Paramount Market Publishing.

Patton, M. Q. (2002). Two decades of developments in qualitative inquiry: A personal, experiential perspective. Qualitative Social Work, 1(3), 261-283. doi:https://doi.org/10.1177/1473325002001003636

Post, S., \& Neimark, J. (2008). Why good things happen to good people: How to live a longer, healthier, happier life by the simple act of giving. New York, NY: Harmony.

Shah, Y. (2014). Study reveals the best prescription for healthy aging. Retrieved from https://goo.gl/TdRVkK (accessed on 23 December 2017)

Sharkey, B. J., \& Gaskill, S. (2013). Fitness \& health. New York, NY: Human Kinetics.

Veenhoven, R. (2009). Enjoyment of life lenghtens life: Findings and consequences. New York, NY: Sage Publication.

Wei, M., Gibbons, L. W., Kampert, J. B., Nichaman, M. Z., \& Blair, S. N. (2000). Low cardiorespiratory fitness and physical inactivity as predictors of mortality in men with type 2 diabetes. Annals of Internal Medicine, 132(8), 605-611. doi: https://doi.org/10.7326/0003-4819-132-8-200004180-00002 
Weldon, B., F. \& Norman. (2014). Does life begin at 80? mail online. Retrieved from https://goo.gl/tSr1KC (accessed on 14 July, 2016)

Wheeler, J. O., \& Holloway, S. R. (2004). Urban geography. New Jersay, NJ: John Wiley \& Sons Inc.

Willcox, D. C., Scapagnini, G., \& Willcox, B. J. (2014). Healthy aging diets other than the mediterranean: A focus on the okinawan diet. Mechanisms of Ageing and Development, 136, 148-162. doi:https://doi.org/10.1016/j.mad.2014.01 .002

Willett, W. (2017). Eat, drink, and be healthy: The harvard medical school guide to healthy eating. New York, NY: Simon and Schuster.

Yin, R. K. (1994). Case study research: Design and methods. Beverly Hills, CA: Sage Publications. 